\title{
Use of the bilobed flap in the pubic region after tumoral lesion excision"
}

\section{Utilização do retalho bilobado na região pubiana após exérese de lesão tumoral}

\author{
Felipe Maurício Soeiro Sampaio ${ }^{1}$ \\ Gustavo Vieira Gualberto ${ }^{2}$ \\ Antonio Carlos Francesconi do Valle ${ }^{3}$
}

\author{
Marcela Duarte Benez Miller \\ Maria Clara Gutierrez Galhardo ${ }^{3}$ \\ Paulo Roberto Cotrim de Souza ${ }^{4}$
}

\begin{abstract}
Reconstruction of surgical defects in the pubic region is a challenge to any surgeon. Our goal was to demonstrate the use of the bilobed flap to reconstruct the pubic region skin after the excision of a recurrent HPV lesion, resistant to conventional treatments. In spite of its classical use in nasal reconstructions, the bilobed flap has applications in extranasal defects, with excellent functional and aesthetic results.

Keywords: HIV; Human papillomavirus 6; surgical flaps

Resumo: A reconstrução de defeitos cirúrgicos na região pubiana é um desafio para qualquer cirurgião. Objetivamos demonstrar a aplicação do retalho bilobado na reconstrução da região pubiana, após excisão de HPV recidivante aos tratamentos convencionais. Apesar da utilização clássica deste retalho ser na região nasal, aplicações em áreas distintas também se mostraram com excelentes resultados funcionais e estéticos.

Palavras-chave: HIV; Papillomavirus humano 6; Retalhos cirúrgicos
\end{abstract}

\section{INTRODUCTION}

Human papilloma virus (HPV) infection is considered one of the most prevalent infections in HIV positive patients, especially in females. ${ }^{1}$ The increase in the incidence, prevalence and persistence of HPV in these patients may be attributed to their susceptibility, cellular immunosuppression and the reactivation of latent foci. ${ }^{2,3}$

Treatment can be performed with podophyllotoxin, 5\% imiquimod cream, trichloroacetic acid, cryotherapy and electrosurgery. Resistant and recurrent cases are indications for a surgical exeresis.

Pubic region reconstructions are usually challenging to any surgeon. In the surgical planning one must consider distension and cutaneous elasticity, a complete knowledge of the anatomical region and the force of contraction at the wound borders.

\section{CASE REPORT}

A fifty-one years old African-American female patient, working as a caregiver for an elderly patient, had clinic and histopathological diagnosis of HPV lesions in the pubic region. During 18 months she was submitted to several sessions of electrocoagulation, cryotherapy and 5\% imiquimod cream, without success. After a two-month absence, the patient returned reporting an accelerated growth of the lesion, which on examination presented as a tumoral lesion, measuring $5 \mathrm{~cm}$ in diameter, with regular, well-defined erythematous borders, and a verrucous yellow surface, painful to palpation (Figure 1).

The patient was positive to human immunodeficiency virus (HIV) since 1996, in treatment with antiretroviral drugs, with an undetectable viral load and a CD4 count over 1,000 cells $/ \mathrm{ml}$.

Received on 09.05.2013.

Approved by the Advisory Board and accepted for publication on 04.06.2013.

* Work performed at Federal Hospital of Bonsucesso (HFB) -Rio de Janeiro (RJ), Brazil.

Conflict of interest: None

Financial funding: None

MD, post-graduation (in course) in dermatology at the Central Army Hospital (HCE)- Fellow of Dermatologic Surgery at the Federal Hospital of Bonsucesso (HFB) -Rio de Janeiro (RJ), Brazil.

Fellow of Dermatologic Surgery at the Federal Hospital of Bonsucesso (HFB) -Rio de Janeiro (RJ), Brazil.

MD, PhD, Dermatologist - Laboratory of Dermatology in Infectious Diseases at the Evandro Chagas Research Institute - Oswaldo Cruz Foundation (IPECFIOCRUZ) - Rio de Janeiro (RJ), Brazil.

MD, chief of the Dermatology Service at the Federal Hospital of Bonsucesso (HFB) -Rio de Janeiro (RJ), Brazil.

C2013 by Anais Brasileiros de Dermatologia 
Due to the therapeutic resistance of the lesion, the co-infection by HIV, the accelerated growth and clinical characteristics of the injury, the hypothesis of transformation to spinocellular carcinoma was suggested.

An excisional biopsy, with $3 \mathrm{~mm}$ security margins was performed. Histopathological examination showed papillomatous epithelial hyperplasia associated to cytophatic viral effects, without cellular atypia, with free margins. The hypothesis of local malignant neoplasm was excluded, thus confirming the diagnosis of HPV.

The residual surgical defect had $6.8 \mathrm{~cm}$ in diameter and to reconstruct it a bilobed flap was used, preserving the function, anatomy and the aesthetics of the pubic and genital areas (Figures 2 and 3).

The surgery was performed under local anesthesia with $2 \%$ lidocaine $(4 \mathrm{ml})$, epinephrine $1 \mathrm{mg} / \mathrm{ml}$ $(0.2 \mathrm{ml})$, sodium bicarbonate $8.4 \%(4 \mathrm{ml})$ and saline solution $0.9 \%$ (31.8 ml), plus perioperative application of $1 \mathrm{~g}$ intravenous cephazolin.

After lobes flap transposition, it was necessary to add two compensatory triangles, the first one close to the right inguinal fold and the second one on the right suprapubic region. The latter facilitated the closing of the flap on its proximal portion. The simple, interrupted sutures, using 4.0-monofilament nylon were performed without residual tension (Figure 4).

With a satisfactory an uncomplicated postoperatory period, the drain was removed in 48 hours and the sutures in 21 days. On the $13^{\text {th }}$ month of ambulatory follow-up, the patient remained without recurrent lesions (Figure 5).

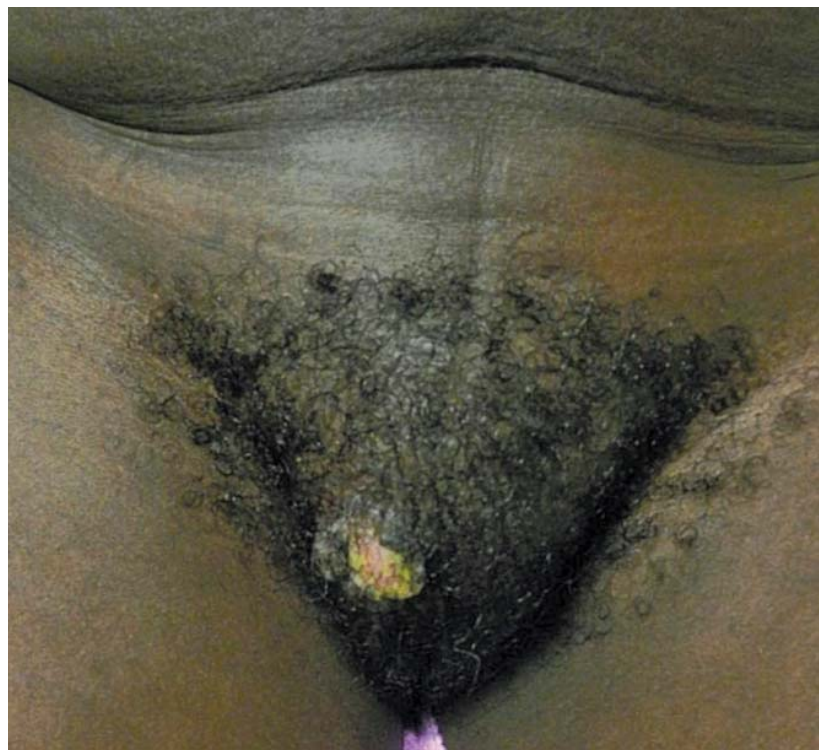

FIGURE 1: Tumoral HPV lesion close to the vaginal area

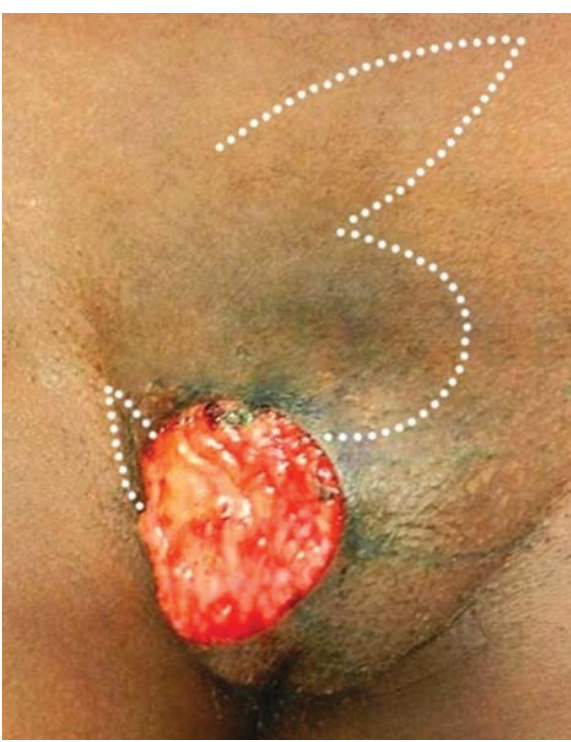

FIGURE 2: Surgical defect after the excision of lesion. The white dotted line shows the bilobed flap design

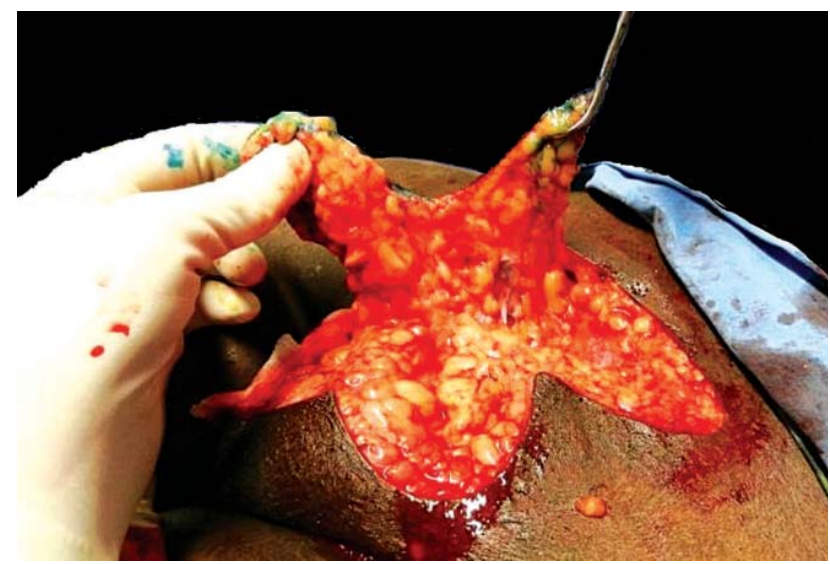

FIGURE 3: Demonstration of lobes forming the bilobed flap

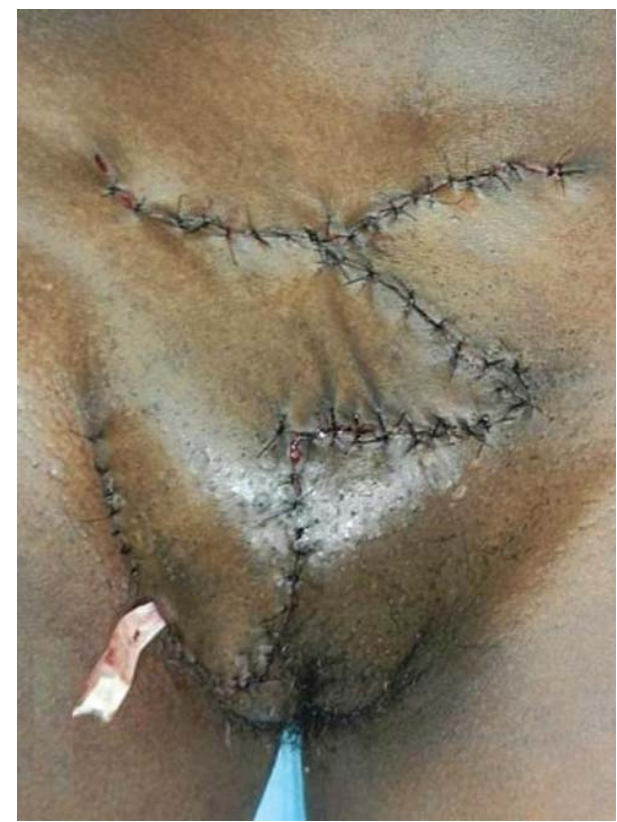

FigURE 4:

Immediate postoperative period with the drain located on the distal portion of the bilobed flap 


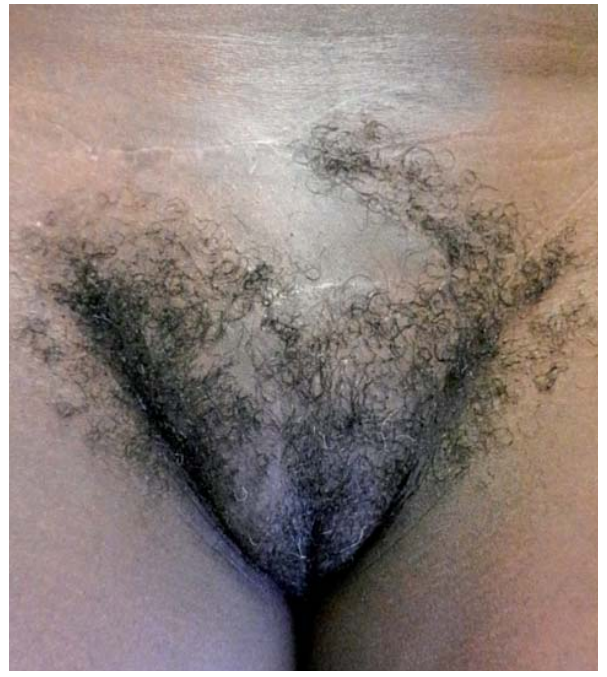

FIGURE 5:

90-day post-operative consultation with excellent cicatrization, function and local aesthetics

\section{DISCUSSION}

Although most of the HPV infections are benign, persistent genital infections with high-risk genomes, such as HPV 16 and 18, may be associated with invasive cervical carcinoma, especially if the patient is infected with HIV. ${ }^{2,3}$ The causal nexus between these infections and cutaneous spinocellular carcinoma remains a topic of discussion. ${ }^{4,5,6}$

\section{REFERENCES}

1. Leto Md, Santos Júnior GF, Porro AM, Tomimori J. Human papillomavirus infection: etiopathogenesis, molecular biology and clinical manifestations. An Bras Dermatol. 2011;86:306-17.

2. Rodgers S, Leslie KS. Skin infections in HIV-infected individuals in the era of HAART Curr Opin Infect Dis. 2011;24:124-9

3. Shrestha S, Sudenga SL, Smith JS, Bachmann LH, Wilson CM, Kempf MC. The impact of highly active antiretroviral therapy on prevalence and incidence of cervical human papillomavirus infections in HIV-positive adolescents. BMC Infect Dis. 2010;10:295

4. Moy RL, Quan MB. The presence of human papillomavirus type 16 in squamous cell carcinoma of the proximal finger and reconstruction with a bilobed transposition flap. J Dermatol Surg Oncol. 1991;17:171-5.

5. Arron ST, Ruby JG, Dybbro E, Ganem D, Derisi JL. Transcriptome sequencing demonstrates that human papillomavirus is not active in cutaneous squamous cell carcinoma. J Invest Dermatol. 2011;131:1745-53.

6. Kansy $\mathrm{K}$, Thiele 0, Freier $\mathrm{K}$. The role of human papillomavirus in oral squamous cell carcinoma: myth and reality. Oral Maxillofac Surg. 2012. [Epub ahead of print]

7. Strahan JE, Cohen JL. Back to basics: expanding the applicability of the bilobed flap. J Drugs Dermatol. 2008;7:1061-5

8. Vyas RM, Pomahac B. Use of a bilobed gracilis myocutaneous flap in perineal and genital reconstruction. Ann Plast Surg. 2010;65:225-7.

9. D'Arpa S, Cordova A, Moschella F. Further application of the bilobed flap: the split bilobed flap for reconstruction of composite posterior auricular and mastoid defects. J Plast Reconstr Aesthet Surg. 2006;59:1330-5.

10. Aasi SZ, Leffell DJ. Bilobed transposition flap. Dermatol Clin. 2005;23:55-64, vi.
The bilobed flap, as reported in this case, is considered a rotational and transpositional cutaneous flap, with two lobes and only one random pedicle. ${ }^{1,7}$ It is classically described for nasal reconstructions, and lately for other anatomical sites such as dorsal area of the hand, malar region, palpebral, retro-auricular, axillary, plantar, perineal and vaginal regions. . $^{4,8,9}$

This type of flap provides a one-time reconstruction, with good elasticity and vascularization and preserves the local anatomy. It is a feasible indication for lesions that will not primarily close edge-to-edge or which would probably result in anatomical distortions if let to heal by second intention.

This type of flap can promote some complications such as trapdoor deformity, anatomical distortions, necrosis, scaring out of the cutaneous relaxing lines and cicatricial retraction. ${ }^{7,10}$

The understanding of human anatomy and the biomechanics of the flaps, provides the surgeon the choice of surgical technique to be used, regardless of the affected area.

\author{
MAILING ADDRESS: \\ Felipe Maurício Soeiro Sampaio \\ Rua Marino da Costa, 217 - Apto 201 \\ 21940-210 - Ilha do Governador - RJ \\ Brazil \\ E-mail: felipemauricio@uol.com.br
}

How to cite this article: Sampaio FMS, Miller MDB, Gualberto GV, Galhardo MCG, do Valle ACF, de Souza PRC. Use of the bilobed flap in the pubic region after tumor excision. An Bras Dermatol. 2013;88(6 Suppl 1):S224-6. 